\title{
PESTICIDE RESIDUES MONITORING IN UNDERGROUND DRINKING WATER, NEUQUÉN PROVINCE, NORTHERN PATAGONIA, ARGENTINA
}

\author{
Monitoreo de residuos de plaguicidas en aguas subterráneas para consumo humano
} en la provincia de Neuquén, Patagonia norte, Argentina

\author{
Victoria Guadalupe SÁNCHEZ ${ }^{1,2 *}$, César Argentino GUTIÉRREZ ${ }^{3}$, Diego Sebastian GOMEZ ${ }^{2,4}$, \\ Miriam LOEWY ${ }^{2}$ and Natalia GUIÑAZÚ ${ }^{2,4}$
}

${ }^{1}$ Departamento de Química, Facultad de Ingeniería, Universidad Nacional del Comahue, Buenos Aires 1400, Neuquén C.P. 8300, Argentina

${ }^{2}$ Centro de Investigaciones en Toxicología Ambiental y Agrobiotecnología del Comahue, Consejo Nacional de Investigaciones Científicas y Técnicas, Universidad Nacional del Comahue, Buenos Aires 1400, Neuquén C.P. 8300 , Argentina

${ }^{3}$ Agencia de Extensión Rural, Instituto Nacional de Tecnología Agropecuaria, Autovía 22 circunvalación s/n, barrio Colonia San Francisco, Plottier C.P. 8316, Argentina

${ }^{4}$ Departamento de Ciencias del Ambiente, Facultad de Ciencias del Ambiente y la Salud, Universidad Nacional del Comahue, Buenos Aires 1400, Neuquén C.P. 8300, Argentina

*Corresponding author: vickyzksanchez@gmail.com

(Received October 2017; accepted September 2018)

Key words: groundwater, organophosphates, carbamates, agriculture

\begin{abstract}
Neuquén province is located in the west of Argentina, at the northern end of Patagonia. In this province, information regarding groundwater distribution and quality is very scarce, and the monitoring of water resources quality is not carried out periodically. It is well known that several pesticide families, such us organophosphates, carbamates and neonicotinoids, are applied in this region to maintain crop quality and production. Pesticide application by ground-based spraying equipment, the climatic conditions and the physical and chemical properties of these compounds, facilitate that a substantial fraction of the active ingredient may reach air, soil and water sources. The objective of this study was to evaluate the pesticide presence in groundwater, in order to provide information about the water quality for human consumption. Seventeen organophosphate and four carbamate residues were monitored from 2014 to 2015 by gas chromatography with a nitrogen-phosphorus detector, in groundwater samples collected from depth wells, located in rural areas corresponding to Senillosa, Plottier, Vista Alegre and Centenario cities, in Neuquén province. These cities are intensive agricultural areas, which supply the North Patagonia region with fresh fruits and vegetables, and where groundwater is utilized for human consumption. In this study, organophosphate and carbamate concentrations were below 0.020 and $0.030 \mu \mathrm{g} / \mathrm{L}$, respectively, and lower than the accepted limits established by the Guidelines for Canadian drinking water quality (2017) and the Guidelines for drinking water quality (2011) of the World Health Organization for these pesticides.
\end{abstract}

Palabras clave: agua subterránea, organofosforados, carbamatos, agricultura 


\section{RESUMEN}

La provincia de Neuquén está ubicada al oeste de Argentina, en el extremo norte de la Patagonia. En esta provincia, la información sobre la distribución y calidad de las aguas subterráneas es muy escasa y el monitoreo de la calidad de los recursos hídricos no se realiza periódicamente. Es bien sabido que en esta región se aplican varias familias de pesticidas, tales como organofosforados, carbamatos y neonicotinoides, para mantener la calidad y la producción de los cultivos. La aplicación de pesticidas por equipos de pulverización en tierra, las condiciones climáticas y las propiedades físicas y químicas de estos compuestos, facilitan que una fracción sustancial del ingrediente activo pueda llegar a las fuentes de aire, suelo y agua. El objetivo de este estudio fue evaluar la presencia de plaguicidas en aguas subterráneas, con el fin de proporcionar información sobre la calidad del agua para consumo humano. Diecisiete organofosforados y cuatro carbamatos fueron monitoreados entre 2014 y 2015 por cromatografía de gases con detector de nitrógeno-fósforo, en muestras de aguas subterráneas recogidas de pozos profundos ubicados en zonas rurales correspondientes a las ciudades de Senillosa, Plottier, Vista Alegre y Centenario, en la provincia de Neuquén. Estas ciudades son zonas agrícolas intensivas, que abastecen a la región norte de Patagonia con frutas y verduras frescas, y donde el agua subterránea se utiliza para consumo humano. En este estudio, la concentración de organofosforados y carbamatos fue menor a 0.020 y $0.030 \mu \mathrm{g} / \mathrm{L}$, respectivamente, e inferior a los límites aceptables establecidos por la guías para la calidad del agua potable de Canadá (2017) y de la Organización Mundial de la Salud (2011) para estos plaguicidas.

\section{INTRODUCTION}

Argentina is the first pears exporter in the Southern Hemisphere and the fifth of apples worldwide. In 2012, 50000 ha with artificially added irrigation produced $1400000 \mathrm{t}$ of pears and apples, with $650000 \mathrm{t}$ being exported. The apples and pears productive areas in Neuquén province represent a $15 \%$ of the 50000 ha implanted with fruit, which corresponds to $34 \%$ of the country's export earnings (Toranzo 2016). In addition, horticultural activity is also important in our country. It is estimated that the annual vegetable production is approximately 8-10 million tons, being produced in an area from 450000 to 500000 ha (including legumes). The main destination of these products is the domestic market $(92-93 \%)$, while $7-8 \%$ is exported. In 2011, the export volume of fresh vegetables and legumes was 831000 t (Fernández-Lozano 2012). In Neuquén province, intensive horticulture covers an area of $1746.5 \mathrm{ha}$. Approximately, the $80 \%$ of vegetal production (mainly pumpkin or potato) is sold in the capital city, the rest being distributed to other areas in this and other provinces (Zanetta 2010).

In Argentina, integrated pest management is critical to maintain production levels and quality standards. It combines several practices to control pests, being the chemical control the most used. The agrochemical market reflects the extended national use of agrochemicals, since sales increased from 2009 to date. Pesticide sales in Argentina are led by herbicides (64\%), insecticides $(16 \%)$ and fungicides (12\%) (CASAFE 2012). The insecticide class that is used depends on the pest to be controlled and the crop type. In the North Patagonian region, the main pesticide families used are organophosphates (OP), carbamates (CAR) and neonicotinoids for pears and apples (Cichón et al. 2015), while for horticulture production the first two predominate (Zanetta 2012).

Pesticides use in agriculture may lead to surface and ground water contamination by drift, runoff and leaching. Contamination of surface water by pesticides in the North Patagonia was demonstrated by Loewy et al. (2011). Contamination depends on the agricultural season, with the highest residue level found in spring and summer (Loewy et al. 2011).

Groundwater is the largest freshwater reservoir in the world, accounting for over $97 \%$ of all available fresh water in the planet, excluding glaciers and ice caps. The remaining $3 \%$ is essentially surface water such as lakes, rivers, wetlands and soil moisture, indicating the importance of groundwater as a resource and the need of commitment to its protection. Groundwater represents the most important source of drinking water supply in many countries (UNESCO 2004). In Argentina, one of three individuals 
consumes groundwater (Calcagno et al. 2000, Santagni et al. 2007). Despite the importance of groundwater resource, pesticide pollution has not been extensively studied in Neuquén province.

The objective of this study was to evaluate the presence of pesticides in drinking groundwater in rural areas where chemicals are intensively applied, in order to provide information about water quality for human consumption.

\section{MATERIALS AND METHODS}

\section{Site description}

Neuquén province is located in the west of Argentina, at the northern end of Patagonia. The study area corresponded to rural areas of Senillosa, Plottier, Vista Alegre and Centenario cities. These are small cities surrounded by the Neuquén and Limay rivers (Fig. 1). These cities are part of the "horticultural belt" that supplies the region with fresh fruits and vegetables. Here, producers have small and medium land surfaces with great crops diversity. Most products are marketed in the region, in supermarkets and in the Mercado Concentrador de Neuquén. The latter is the most important market regarding sales volumes and supplies with horticultural products, concentrating the offer from October-November to March-April (Zanetta 2012). According to data obtained from Instituto Nacional de Estadísticas y Censo (INDEC) in the year 2001, Neuquén province had 474155 inhabitants. Particularly, the department of Confluencia (the studied area) had 314793 inhabitants, representing $66.4 \%$ of the total population (INDEC 2010). This

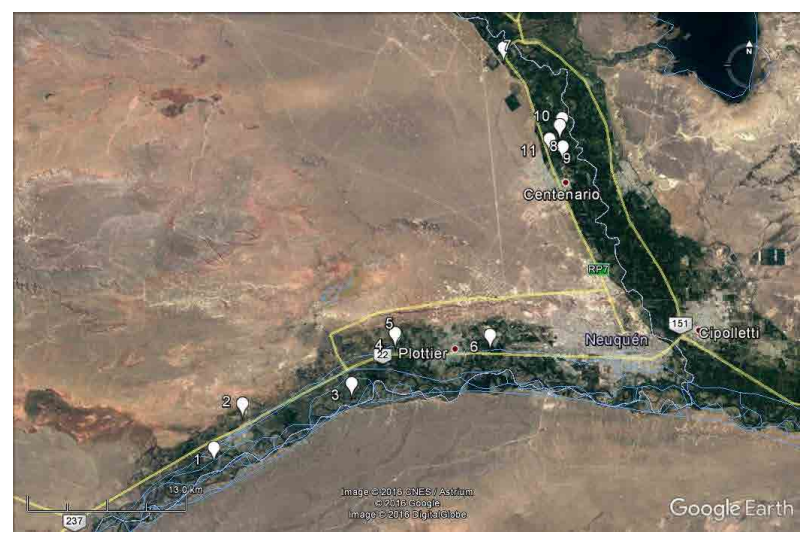

Fig.1. Map of groundwater monitoring sites in Neuquén province, Northern Patagonia, Argentina area shows climatic characteristics such as low humidity, average annual precipitation below 250 $\mathrm{mm}$, high sunshine and a prevailing west-east wind direction. These winds are stronger in spring and summer. The average temperature is $13.4^{\circ} \mathrm{C}$, with great thermal amplitude.

\section{Characterization of producers and agricultural practices}

The study was performed in farms with areas from 2 to 25 ha, each of them producing more than three crops per season and receiving technical assistance from state organizations. Their production includes pome fruit (apples and pears), fine fruits (cherry, raspberry and strawberry) and vegetables (tomatoes, chard, lettuce, potatoes and onions). The pests to be controlled mainly include codling moth (Cydia pomonella), whitefly (Aleyrodidae), small insects (Thysanoptera, Aphididae), European red mite (Panonychus), and caterpillar (Rachiplusia). The chemical control is performed with OP, CAR and neonicotinoids. The pesticide most commonly applied is chlorpyrifos (information obtained through interviews).

Pesticide application usually occurs between October and March, with a frequency of up to eight times. Applications are performed with ground-based spraying equipment (pesticides are usually finely dispersed as droplets or particles at the time of pulverization). Even though the targets of pesticide application are pests on the plant, a substantial fraction of the active ingredient reaches the soil and surface water (Loewy et al. 2011).

\section{Sampling and pesticide analysis}

Samples were collected in December 2014 and 2015 , since the highest pesticide concentrations were reported in surface waters in these months (Loewy et al. 2011), which correspond to the highest agrochemical application rate. The pesticides investigated were OP: azinphos-ethyl, azinphos-methyl (AM), chlorfenvinphos, chlorpyrifos (CPF), diazinon, dichlorvos, dimethoate, fenamiphos, fenitrothion, fenthion, malathion, methidathion, mevinphos, parathionethyl, parathion-methyl, phosmet, triazophos; and CAR: carbaryl, carbofuran, pirimicarb and propoxur.

Eleven groundwater samples (3-25 $\mathrm{m}$ deep) from different sites were collected in amber glass bottles (approx. $1000 \mathrm{~mL}$ ), were refrigerated, transported to the laboratory and analyzed within $48 \mathrm{~h}$. Water samples were extracted and analyzed for OP and CAR pesticides. Samples were first filtered and then extracted with solid phase extraction (SPE) using C18 columns (Strata Phenomenex), which were previously 
treated with methanol $6 \mathrm{~mL}$ followed by water $6 \mathrm{~mL}$. Pesticides were eluted with hexane $2 \mathrm{~mL}$, followed by dichloromethane $4 \mathrm{~mL}$. These extracts were dried in a nitrogen stream and then dissolved in hexane, $0.25 \mathrm{~mL}$ according to the EPA 3535A modified method (EPA 1998). Internal standard, $25 \mu \mathrm{L}$ (Sulfotep $1.085 \mathrm{mg} / \mathrm{L}$ ) was added to samples and analyzed by gas chromatography (GC) using an Agilent 6890 GC equipped with an Agilent 7683 autosampler, split/splitless injector $\left(250^{\circ} \mathrm{C}\right)$ and a nitrogen-phosphorus detector at $300^{\circ} \mathrm{C}$. GC conditions were as follows: GC column, capillary column HP5 (30 m in length, $0.32 \mathrm{~mm}$ i.d., $0.25 \mu \mathrm{m}$ film thickness). Nitrogen was used as a carrier gas at a flow rate of $2 \mathrm{~mL} / \mathrm{min}$. The column temperature was programmed from 70 to $240{ }^{\circ} \mathrm{C}$; injection volume: 2 $\mu \mathrm{L}$. The OP pesticides detection (DL) and quantitation (LOQ) limits were 0.020 and $0.060 \mu \mathrm{g} / \mathrm{L}$, respectively. For CAR pesticides, $\mathrm{DL}=0.030$ and $\mathrm{LOQ}=0.110$ $\mu \mathrm{g} / \mathrm{L}$; for chlorpyrifos, $\mathrm{DL}=0.014$ and $\mathrm{LOQ}=0.050$ $\mu \mathrm{g} / \mathrm{L}$, and for methidathion, $\mathrm{DL}=0.010$ and $\mathrm{LOQ}=$ $0.030 \mu \mathrm{g} / \mathrm{L}$.

\section{Quality control}

In all cases, Sulfotep was added to the final extracts as an internal standard. Overall, mean recoveries were between 75 and $110 \%$ and coefficient of variation $<20 \%$. A blank was analyzed with each extraction set. Analytical grade chemicals (purity $>$ $99 \%$ ) purchased from Chemservice (West Chester, PA), were used as reference standards.

\section{RESULTS AND DISCUSSION}

Data related to groundwater pesticide monitoring are generally scarce in many world regions. In Argentina, the high analysis cost and the seasonal spraying variation often preclude the gathering of representative and extensive data sets. In this country, monitoring has been performed in different intensive agricultural regions and the presence of agrochemicals in matrices such as fruits and vegetables, soil and water has been demonstrated (Hjorth et al. 2011, Zanetta 2012, Bonansea et al. 2013, Miglioranza et al. 2013, VillaamilLepori et al. 2013). Particularly, in Neuquén province information regarding groundwater distribution and quality is very scarce and disjointed. Hydrogeological maps are not available and water resource quality monitoring is not carried out periodically (Calcagno et al. 2000). In the Limay and Neuquén rivers basin, problems regarding water quality were mainly associated with agriculture and urban use (Calcagno et al. 2000). Loewy et al. (2011) found residues of some of the studied pesticides in soil, surface water, and shallow groundwater compartments. The highest detection frequencies in water (surface and subsurface) were due to azinphos-methyl (AM) and CPF (> 70\%). In terms of concentration, the highest levels were observed in shallow groundwater for AM $(22.5 \mu \mathrm{g} / \mathrm{L})$ and carbaryl $(45.7 \mu \mathrm{g} / \mathrm{L})$. These results led us to search those compounds in drinking groundwater, since the background levels found in shallow groundwater justify the investigation of residues to greater depths where water is used as drinking supply.

In the current report, 11 sites were selected according to the water contamination potential risk by pesticide use. Residues of seventeen OP and four CAR were monitored in the groundwater samples collected from depth wells in rural areas. Table I shows groundwater samples location data and physicochemical properties. Measured $\mathrm{pH}$ values were between 6.63 and 7.10 and total dissolved solids (TSD), estimated from the conductivity data, were

TABLE I. LATITUDE AND LONGITUDE DATA OF THE AREA STUDIED, $\mathrm{pH}$ AND CONDUCTIVITY OF GROUNDWATER

\begin{tabular}{|c|c|c|c|c|}
\hline $\begin{array}{c}\text { Code of } \\
\text { water well }\end{array}$ & $\begin{array}{l}\text { Latitude and } \\
\text { longitude }\end{array}$ & $\begin{array}{l}\text { Depth of } \\
\text { well (m) }\end{array}$ & $\mathrm{pH}$ & $\begin{array}{c}\text { Conductivity } \\
(\mathrm{mS} / \mathrm{cm})\end{array}$ \\
\hline 1 & $\begin{array}{l}39^{\circ} 02^{\prime} 11.8^{\prime \prime} \mathrm{S} \\
68^{\circ} 27^{\prime} 22.9^{\prime \prime} \mathrm{W}\end{array}$ & 7 & 6.87 & 0.36 \\
\hline 2 & $\begin{array}{c}39^{\circ} 00^{\prime} 15^{\prime \prime} \mathrm{S} \\
68^{\circ} 25^{\prime} 44.7^{\prime \prime} \mathrm{W}\end{array}$ & 6 & 7.10 & 0.77 \\
\hline 3 & $\begin{array}{l}38^{\circ} 59^{\prime} 21.8^{\prime \prime} \mathrm{S} \\
68^{\circ} 19^{\prime} 31.0^{\prime \prime} \mathrm{W}\end{array}$ & 8 & 6.84 & 0.17 \\
\hline 4 & $\begin{array}{l}38^{\circ} 57^{\prime} 09.3^{\prime \prime} \mathrm{S} \\
68^{\circ} 17^{\prime} 02.3 ” \mathrm{~W}\end{array}$ & 8 & 6.79 & 0.33 \\
\hline 5 & $\begin{array}{l}38^{\circ} 57^{\prime} 15.2 " 1{ }^{\prime \prime} \mathrm{S} \\
68^{\circ} 17^{\prime} 06.1 ” \mathrm{~W}\end{array}$ & 6 & 6.73 & 0.64 \\
\hline 6 & $\begin{array}{l}38^{\circ} 57^{\prime} 14.8^{\prime \prime} \mathrm{S} \\
68^{\circ} 11^{\prime} 37.3 ” \mathrm{~W}\end{array}$ & 7 & 6.83 & 0.26 \\
\hline 7 & $\begin{array}{l}38^{\circ} 44^{\prime} 33.2^{\prime \prime} \mathrm{S} \\
68^{\circ} 10^{\prime} 50.7^{\prime \prime} \mathrm{W}\end{array}$ & 6 & 6.78 & 2.17 \\
\hline 8 & $\begin{array}{l}38^{\circ} 47^{\prime}, 58.4^{\prime \prime} \mathrm{S} \\
68^{\circ} 07^{\prime} 39.0 " \mathrm{~W}\end{array}$ & 7 & 6.63 & 0.55 \\
\hline 9 & $\begin{array}{l}38^{\circ} 48^{\prime} 55.7^{\prime \prime} \mathrm{S} \\
68^{\circ} 07^{\prime} 28.8^{\prime \prime} \mathrm{W}\end{array}$ & 8 & 6.85 & 0.98 \\
\hline 10 & $\begin{array}{l}38^{\circ} 47^{\prime} 40.2^{\prime \prime} \mathrm{S} \\
68^{\circ} 07^{\prime} 31.0 " \mathrm{~W}\end{array}$ & 25 & 7.01 & 0.36 \\
\hline 11 & $\begin{array}{l}38^{\circ} 48^{\prime}, 35.2^{\prime \prime} \mathrm{S} \\
68^{\circ} 08^{\prime} 14.2 " \mathrm{~W}\end{array}$ & 3 & 6.84 & 0.66 \\
\hline
\end{tabular}


below $500 \mathrm{mg} / \mathrm{L}$ (except for well $\mathrm{N}^{\mathrm{o}} 7$ ), both within the limits established for drinking water (WHO 2011, Health Canada 2017). These parameters are physical and chemical data usually measured in order to easily detect possible anomalies in the water quality. Parameters out of the established for this use, especially $\mathrm{pH}$, may promote pesticide degradation but could be harmful for human health.

Table II summarizes the OP and CAR pesticides content, DLs, classification according to the World Health Organization (WHO), groundwater ubiquity score (GUS index) (Gustafson 1989) and the environmental and health guideline values (WHO 2011, Health Canada 2017). Pesticides monitored in this study were classified by WHO as extremely, highly or moderately hazardous (Ia, Ib and II, respectively), since they comprise neurotoxic compounds and endocrine disruptors capable of generating reproductive problems. Only malathion was classified by WHO as slightly hazardous. It has been reported that environmental pesticide exposure of rural residents occurs in this region (Cecchi et al. 2012, Sánchez et al. 2014, Rivero-Osimani et al. 2016); moreover, pesticide residues, especially CPF, have been found in soil, fruits and vegetables in the area (Zanetta 2012). CPF was found both in crops where the use of the active ingredient is unregistered (lettuce, zucchini, eggplant, chard and beet) and in crops where it is registered (tomatoes, onions and peppers) (SENASA 2010).

Groundwater pesticides contamination may come from percolation agricultural irrigation or surface water through soil layers. This phenomenon is governed by the physical and chemical characteristics of the compounds (solubility in water, their capacity to be retained by soil components and their degradation rate), the properties of the soil in which they are applied (Caracciolo et al. 2010) and other external factors, such as local rainfall and wind patterns or the topography of the area (Toan et al. 2013). The OP studied showed low-leaching indexes except for chlorfenvinphos and triazophos, which have an intermediate index value. On the other hand, within the CAR group, only propoxur possess a high leaching index; however, this is not so widely used in the studied region. Carbaryl, carbofuran and pirimicarb have intermediate index values. Nevertheless, the GUS index is based on the physical and chemical properties of the compounds, but disregards the environmental conditions, the field application rate, application timing and formulation (IUPAC 2018).

Environmental conditions and agricultural practices are essential to assess environment pesticides mobility and distribution (Székács et al. 2015).
In this sense, Menike et al. (2012) investigated the interrelationships between CPF concentrations in water resources, $\mathrm{CPF}$ application, and rainfall during the peak of the pesticide application period with a usual rainfall pattern in Sri Lanka. Despite their low GUS values, high performance liquid chromatography analyses revealed that average $\mathrm{CPF}$ concentrations in groundwater and surface water samples were 0.63 and $0.52 \mu \mathrm{g} / \mathrm{L}$, respectively. In contrast to these results, all OP and CAR concentrations in this study were below the established limits, even below the DL and in accordance with the GUS values (Table II). In other countries, pesticide residues were found in soil, air and water in several sites with various climatic and topographical features. For example, in Ghana CPF (0.01-0.04 mg/kg), profenofos (0.02$0.04 \mathrm{mg} / \mathrm{kg}$ ) and pirimiphos-methyl (0.01-0.04 mg/ $\mathrm{kg}$ ) residues were detected in soil samples, while OP residues recorded in the water samples were CPF, 0.01-0.05 $\mu \mathrm{g} / \mathrm{L}$; diazinon, 0.01-0.04 $\mu \mathrm{g} / \mathrm{L}$, and pirimiphos-methyl, 0.01-0.03 $\mu \mathrm{g} / \mathrm{L}$. The concentration of $\mathrm{CPF}$ and diazinon residues exceeded their respective values according to the WHO guidelines for drinking water (Fosu-Mensah et al. 2016).

In another research, Pozo et al. (2016) analyzed air samples from sites located in agricultural areas in the Araucanía region, Chile. They found that CPF concentration in air ranged from $20-14600 \mathrm{pg} / \mathrm{m}^{3}$. The highest CPF concentrations were detected at the Angol sites $\left(\sim 14600 \mathrm{pg} / \mathrm{m}^{3}\right)$ during AugustDecember 2008. These values were higher than those detected in Villarica in the same period. They concluded that air masses from nearby agricultural zones may have contributed to the CPF levels detected in this period. Particularly, CPF detected values in Angol were higher at low wind speed. In the North Patagonia region, Loewy et al. (2006) observed an inverse correlation between AM concentrations in shallow groundwater and the time elapsed since the last pesticide application. Seasonal events such as rain and irrigation influenced the chemical concentration in groundwater; however, they did not obtain a correlation between soil characteristics and the AM concentration. They concluded that the soil attenuation capacity was not enough to prevent the presence of AM in the aquifer during the application season.

The present study was developed at the same region where topsoil has medium to thick textures, with low contents of organic matter (0.5-1.5\%) and $\mathrm{pH}$ values between 6.8 and 8.2. Nevertheless, OP (including AM) and CAR concentrations in groundwater were below the DLs (Table II). These results 
TABLE II. ANALYZED PESTICIDES IN DRINKING GROUNDWATER

\begin{tabular}{|c|c|c|c|c|c|}
\hline Pesticides & $\begin{array}{l}\text { Concentration } \\
(\mu \mathrm{g} / \mathrm{L})\end{array}$ & $\begin{array}{c}\mathrm{DL} \\
(\mu \mathrm{g} / \mathrm{L})\end{array}$ & $\begin{array}{l}\text { Guideline values } \\
\text { (mg/L) }\end{array}$ & $\begin{array}{l}\text { WHO } \\
\text { class }^{\mathrm{c}}\end{array}$ & GUS \\
\hline \multicolumn{6}{|c|}{ Organophosphates } \\
\hline Azinphos-ethyl & ND & 0.020 & - & $\mathrm{Ib}$ & 1.40 \\
\hline Azinphos-methyl & ND & 0.020 & $20^{\mathrm{a}}$ & $\mathrm{Ib}$ & 0.24 \\
\hline Chlorfenvinphos & ND & 0.020 & - & $\mathrm{Ib}$ & 1.83 \\
\hline Chlorpyrifos & ND & 0.014 & $30^{\mathrm{b}}$ & II & 0.17 \\
\hline Diazinon & ND & 0.020 & $20^{\mathrm{a}}$ & II & 1.14 \\
\hline Dichlorvos & ND & 0.020 & - & $\mathrm{Ib}$ & 0.69 \\
\hline Dimethoate & ND & 0.020 & $6^{\mathrm{b}}$ & II & 1.06 \\
\hline Fenamiphos & ND & 0.020 & $\begin{array}{l}\text { Unlikely to occur in } \\
\text { drinking water }\end{array}$ & $\mathrm{Ib}$ & -0.11 \\
\hline Fenitrothion & ND & 0.020 & $\begin{array}{l}\text { Occurs in drinking } \\
\text { water at concentra- } \\
\text { tions well below those } \\
\text { of health concern }\end{array}$ & II & 0.48 \\
\hline Fenthion & ND & 0.020 & - & II & 1.26 \\
\hline Malathion & ND & 0.020 & $190^{\mathrm{a}}$ & III & -1.28 \\
\hline Methidathion & $\mathrm{ND}$ & 0.010 & - & $\mathrm{Ib}$ & 1.40 \\
\hline Mevinphos & ND & 0.020 & - & Ia & 1.12 \\
\hline Parathion-ethyl & ND & 0.020 & - & Ia & 1.42 \\
\hline Parathion-methyl & ND & 0.020 & $\begin{array}{l}\text { Occurs in drinking } \\
\text { water at concentra- } \\
\text { tions well below those } \\
\text { of health concern }\end{array}$ & Ia & 1.46 \\
\hline Phosmet & ND & 0.020 & - & II & 0.24 \\
\hline Triazophos & ND & 0.020 & $\begin{array}{l}\text { Unlikely to occur in } \\
\text { drinking water }\end{array}$ & $\mathrm{Ib}$ & 2.38 \\
\hline \multicolumn{6}{|c|}{ Carbamates } \\
\hline Carbaryl & ND & 0.030 & $90^{\mathrm{a}}$ & II & 2.02 \\
\hline Carbofuran & ND & 0.030 & $7^{\mathrm{b}}$ & $\mathrm{Ib}$ & 2.28 \\
\hline Pirimicarb & ND & 0.030 & - & II & 2.73 \\
\hline Propoxur & ND & 0.030 & $\begin{array}{l}\text { Unlikely to occur in } \\
\text { drinking water }\end{array}$ & II & 3.73 \\
\hline
\end{tabular}

ND: not detected, DL: detection limit, GUS: leaching potential index (IUPAC 2018)

${ }^{\mathrm{a}}$ Canadian guidelines for drinking water quality 2017 (Health Canada 2017); ${ }^{\mathrm{b}} \mathrm{WHO}$ guidelines for drinking water quality (WHO 2011); ${ }^{c}$ WHO toxicity classes: class Ia: extremely hazardous, class Ib: highly hazardous, class II: moderately hazardous, class III: slightly hazardous (IUPAC 2018). 
could be explained by a longer migration time and a greater soil attenuation capacity, which could allow pesticides degradation before reaching deeper groundwater sources (Table I). An interesting fact to highlight is that AM application in Argentina was definitely banned in 2017 (SENASA 2016).

Routine monitoring is essential to detect pollution sources at early stages and represents a critical element of pesticide management plans. It is a useful tool which provides the information needed to make decisions and to regulate pesticide application schemes in order to protect drinking water sources. Although the investigated pesticides did not exceed the limits of drinking-water criteria, this study may not provide a complete assessment of the overall health and environmental risks associated to the presence of pesticides in groundwater. In this sense, pesticide compounds that were not examined in this study could be present in groundwater and could also represent potential health risks.

\section{CONCLUSION}

Pesticide residues monitoring is an important tool to know the groundwater quality and to prevent and control possible environmental pollution in the study area. Argentina should develop a groundwater monitoring network by regions and gather information in order to generate regulatory frameworks and to protect human and environmental health. It is also important to include monitoring of other matrices such as soil, fruit, air and surface water to get a broad perspective of the local situation in relation to pesticide pollution.

The present work demonstrates that although shallow groundwater is susceptible to be contaminated by pesticide residues, deeper groundwater is still protected against pesticide contamination beyond the studied conditions. This work also sets a precedent in the Northern Patagonia, by determining the groundwater quality for human consumption in an area of intensive agricultural production.

\section{ACKNOWLEDGMENTS}

Financial support was received from the Agencia Nacional de Investigaciones Científicas y Técnicas (PICT $2012 \mathrm{~N}^{\circ} 1718$ ) and the Universidad Nacional del Comahue (04-N021). Victoria Sánchez thanks the Consejo Nacional de Investigaciones Científicas y Técnicas for the fellowship granted.

\section{REFERENCES}

Bonansea R.I., Amé M.V. and Wunderlin D.A. (2013). Determination of priority pesticides in water samples combining SPE and SPME coupled to GC-MS. A case study: Suquía River basin (Argentina). Chemosphere 90 (6), 1860-1869.

DOI: 10.1016/j.chemosphere.2012.10.007

Calcagno A., Mendiburo N. and Gaviño-Novillo M. (2000). Informe sobre la gestión de agua en la República Argentina [online]. http://www.cepal.org/ drni/proyectos/samtac/inar00200.pdf 21/08/2018

Caracciolo A.B., Fajardo C., Grenni P., Saccà M.L., Amalfitano S., Ciccoli R., Martin M. and Gibello A. (2010). The role of a groundwater bacterial community in the degradation of the herbicide terbuthylazine. FEMS Microbiol. Ecol. 71 (1), 127-136. DOI: 10.1111/j.1574-6941.2009.00787.x

CASAFE 2012. Mercado argentino de productos fitosanitarios. Cámara de Sanidad Agropecuaria y Fertilizantes [online]. http://www.casafe.org/publicaciones/estadisticas/ 07/09/2018

Cecchi A., Rovedatti M.G., Sabino G. and Magnarelli G.G. (2012). Environmental exposure to organophosphate pesticides: Assessment of endocrine disruption and hepatotoxicity in pregnant women. Ecotoxicol. Environ. Saf. 80, 280-287. DOI: 10.1016/j.ecoenv.2012.03.008

Cichón L., Garrido S.A. and Araque L. (2015). Residuos $\mathrm{y}$ tolerancias de insecticidas para el control de plagas de frutales de pepita. Instituto Nacional de Tecnología Agropecuaria [online]. http://inta.gob.ar/sites/default/ files/inta_residuos-y-tolerancias-de-insecticidas_actualizacion-2015_0.pdf 21/08/2018

EPA (1998). Method 3535A. Solid phase extraction. Environmental Protection Agency [online]. http://www. epa.gov/sites/production/files/2015-06/documents/ epa-3535a.pdf 21/08/2018

Fernández-Lozano J. (2012). La producción de hortalizas en Argentina. Report. Gerencia de calidad y tecnología, Secretaría de Comercio Interior, Corporación del Mercado Central de Buenos Aires, Buenos Aires, Argentina, 29 pp.

Fosu-Mensah B.Y., Okoffo E.D., Darko G. and Gordon C. (2016). Organophosphorus pesticide residues in soils and drinking water sources from cocoa producing areas in Ghana. Environ. Syst. Res. 5 (10), 1-12. DOI: $10.1186 / \mathrm{s} 40068-016-0063-4$

Gustafson D.I. (1989). Groundwater ubiquity score: A simple method for assessing pesticide leachability. Environ. Toxicol. Chem. 8 (4), 339-357. DOI: $10.1002 /$ etc.5620080411 
Health Canada (2017). Guidelines for Canadian drinking water quality summary table. Federal-ProvincialTerritorial Committee on Drinking Water, Canada [online]. https://www.canada.ca/content/dam/hc-sc/ migration/hc-sc/ewh-semt/alt_formats/pdf/pubs/watereau/sum_guide-res_recom/sum_guide-res_recom-eng. pdf 04/09/2018

Hjorth K., Johansen K., Holen B., Andersson A., Christensen H.B., Siivinen K. and Toome M. (2011). Pesticide residues in fruits and vegetables from South America. A Nordic project. Food Control 22 (11), 1701-1706. DOI:10.1016/j.foodcont.2010.05.017

INDEC (2010). Censo Nacional de población, hogares y viviendas. Instituto Nacional de Estadísticas y Censos, República Argentina [online]. http://www.estadisticaneuquen.gob.ar/index.php?sec $=$ censo2010 21/08/2018

IUPAC (2018). Pesticide properties database. International Union of Pure and Applied Chemistry [online]. http:// sitem.herts.ac.uk/aeru/iupac/atoz.htm 21/08/2018

Loewy R.M., Carvajal L.G., Novelli M. and Pechen D'angelo A.M. (2006). Azinphos methyl residues in shallow groundwater from the fruit production region of Northern Patagonia, Argentina. J. Environ. Sci. Health B. 41 (6), 869-881. DOI: $10.1080 / 03601230600805956$

Loewy R.M., Monza L.B., Kirs V.E. and Savini M.C. (2011). Pesticide distribution in an agricultural environment in Argentina. J. Environ. Sci. Health B 46 (8), 662-670.

DOI: 10.1080/03601234.2012.592051

Menike A.M.W., Shanthini R., Kalpage C.S., Karunaratne D.G.G.P. and Anuruddha Kankanamge (2012). Chlorpyrifos contamination of fresh water in a commercial vegetable cultivation area in Sri Lanka and factors affecting contamination. J. Natn. Sci. Foundation Sri Lanka 40 (4), 333-344.

DOI: $10.4038 /$ jnsfsr.v40i4.5047

Miglioranza K.S., González M., Ondarza P.M., Shimabukuro V.M., Isla F.I., Fillmann G., Aizpún J.E. and Moreno V.J. (2013). Assessment of Argentinean Patagonia pollution: PBDEs, OCPs and PCBs in different matrices from the Río Negro basin. Sci. Total Environ. 452-453, 275-285.

DOI:10.1016/j.scitotenv.2013.02.055

Pozo K., Llanos Y., Estellano V.H., Cortes S., Jorquera H., Gerli L., Pozo K., Encina F., Palma R. and Focardi S. (2016). Occurrence of chlorpyrifos in the atmosphere of the Araucanía Region in Chile using polyurethane foam-based passive air samplers. Atmos. Pollut. Res. 7 (4), 706-710

DOI: 10.1016/j.apr.2016.03.003

Rivero-Osimani V.L., Valdez S.R., Guiñazú N. and Magnarelli G. (2016). Alteration of syncytiotrophoblast mitochondria function and endothelial nitric oxide synthase expression in the placenta of rural residents. Reprod. Toxicol. 61, 47-57.

DOI: 10.1016/j.reprotox.2016.02.018

Sánchez S., Vera B., Montagna C. and Magnarelli G. (2014). Characterization of placental cholinesterases and activity induction associated to environmental organophosphate exposure. Toxicol. Rep. 2, 437-442. DOI: $10.1016 /$ j.toxrep.2014.11.013

Santagni A., Loewy R.M. and Montagna M.C. (2007). Contaminación con plaguicidas del agua subterránea para consumo humano en Campo Grande y Cinco Saltos, Río Negro, Argentina. Ingeniería Sanitaria y Ambiental 92, 54-61.

SENASA (2010). Resolución 934/10. Servicio Nacional de Sanidad y Calidad Agroalimentaria [online]. http://www.senasa.gov.ar/normativas/resolucion934-2010-senasa-servicio-nacional-de-sanidad-y calidad-agroalimentaria 21/08/2018

SENASA (2016). Resolución 149/16. Servicio Nacional de Sanidad y Calidad Agroalimentaria [online]. http://www.mptt.gov.ar/site13/index.php/ agroq?download...149...metil-azinfos 21/08/2018

Székács A., Mörtl M. and Darvas B. (2015). Monitoring pesticide residues in surface and ground water in Hungary: Surveys in 1990-2015. J. Chem. 2015, 1-15. DOI: $10.1155 / 2015 / 717948$

Toan P.V., Sebesvari Z., Blasing M. and Renaud F.G. (2013). Pesticide management and their residues in sediments and surface and drinking water in the Mekong Delta, Vietnam. Sci. Total Environ. 452-453, 28-39. DOI:10.1016/j.scitotenv.2013.02.026

Toranzo J. (2016). Producción mundial de manzanas y peras. Programa Nacional Frutales. Estación Experimental Agropecuaria Alto Valle. Instituto Nacional de Tecnología Agropecuaria, Allen, Río Negro, Argentina, $39 \mathrm{pp}$.

UNESCO (2004). Groundwater resources of the world and their use. United Nations Educational, Scientific and Cultural Organization [online]. http://unesdoc.unesco. org/images/0013/001344/134433e.pdf 21/08/2018

Villaamil-Lepori E.C., Bovi-Mitre G. and Nassetta M. (2013). Situación actual de la contaminación por plaguicidas en Argentina. Rev. Int. Contam. Ambie. 29, 25-43.

WHO (2011). Guidelines for drinking water quality. World Health Organization. 4th ed. World Health Organization, Geneva [online]. http://www.unicef.org/cholera/ Chapter_4_prevention/01_WHO_Guidelines_for_ drinking_water_quality.pdf $21 / 08 / 2018$

Zanetta V. (2010). Determinación del status sanitario y estrategias de intervención en cultivos hortícolas sobre un área piloto. Provincia de Neuquén. Final report. 
Consejo Federal de Inversiones. Neuquén, Argentina, 92 pp. [online]. http://biblioteca.cfi.org.ar/wp-content/ uploads/sites/2/2010/01/48626.pdf 04/09/2018

Zanetta V. (2012). Estudio de la situación sanitaria y contaminación de suelos con metabolitos en las producciones hortícolas del Departamento Confluencia.
Final report. Consejo Federal de Inversiones, Neuquén, Argentina, $111 \mathrm{pp}$. [online]. http://biblioteca.cfi.org. ar/documento/estudio-de-la-situacion-sanitaria-ycontaminacion-de-suelos-con-metabolitos-en-las-producciones-horticolas-del-departamento-confluenciaprovincia-del-neuquen/ 04/09/2018 